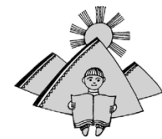

doi: $10.15330 / m s u c .2019 .21 .19-24$

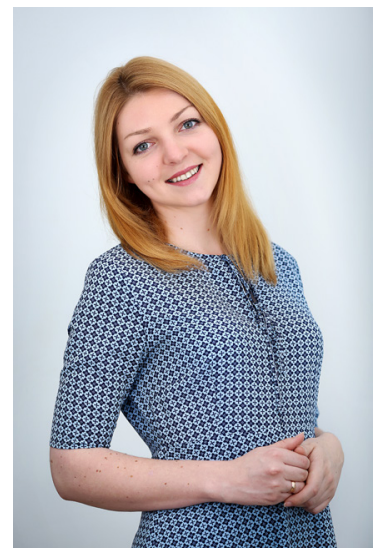

\title{
Орлова Ганна,
}

аспірант Інституту проблем виховання НАПН України

(м. Київ, Україна)

\section{Orlova Hanna,}

postgraduate student,

Institute of Problems on Education of the National

Academy of Educational Sciences of Ukraine

(Kyiv, Ukraine)

orlova.hanna@gmail.com

ORCID ID 0000-0003-0385-2682

УДК [37.091.33:-027.63]:167:159.923.2

\section{СУЧАСНІ СТАНДАРТИЗОВАНІ ЗАРУБІЖНІ МЕТОДИКИ ДОСЛІДЖЕННЯ Я-КОНЦЕПЦІЇ МОЛОДШИХ ШКОЛЯРІВ}

Анотація. В статті розглянуто дванадцять найпопулярніших зарубіжних методик дослідження Я-концепції школярів: Опитувальник самооцінки Розенберга, Опитувальник самооцінки Куперсміта, Шкалу дитячої Я-концепції Пірса-Гарріса, Шкалу Я-концепції Теннессі, Профіль самосприйняття для дітей Хартер, Опитувальник самоопису Марша, Профіль самосприйняття для підлітків Хартер, Рисунковий тест самооцінки компететності та соціального прийняття для дошкільників, Шкалу самооцінки Хейра, Шкалу ситуативної самооцінки Хітертона та Полівого, Багатовимірну шкалу Я-концепції Бракена, Шкалу Я-концепції для дітей Мартінека-Заїчковського. За результатами аналізу встановлено, що всі методики мають добрі показники валідності, надійності та внутрішньої узгодженості. Окремі з них перекладено та адаптовано російською чи українською мовами. Однак в більшості випадків відомості щодо психометричних властивостей адаптованих версій методик авторами не розкриваються. Лише окремі версії методики самосприйняття Хартер представлені у форматі, який дає можливість їх повноцінного практичного застосування. Поряд із цим ряд методик (тест Розенберга та різні версії методики Хартер) мають добрі перспективи впровадження в навчальновиховний процес за належної стандартизації та додаткових досліджень її валідності та надійності.

Ключові слова: Я-концепція, молодший шкільний вік, психодіагностика, психометрика.

\section{MODERN STANDARDIZED METHODS OF MEASURING THE SELF-CONCEPT OF JUNIOR SCHOOL AGE CHILDREN}

\begin{abstract}
The article states that one of the most important tasks of the educational process is the education of a holistic personality, the disclosure of personal potential and the consideration of the individual capabilities of each child. An important prerequisite for this task is the education of a positive self-concept of children, which is the basis of their self-determination, attitude towards themselves, interaction with peers and adults. The self-concept is a rather complex, multi-level personal formation and defines the life path of a person. The process of nurturing the self-concept requires an individual approach to children, which is why high-quality and timely diagnosis of self-concept in schoolchildren, the selection of appropriate methods are important for further education of positive ideas about themselves and self-perception.

The publication states that the study of features of the child's self-concept is of great importance, and therefore the development of appropriate diagnostic methods and techniques. Children come to the first grade with the basics of selfperception and self-concept already laid down in preschool age, on which the individualized education of their I concept in school should be based. Prominent among the methods of research are standardized tests that allow you to quickly study the peculiarities of children's development and to compare the obtained indicators with the normative data in a well-established procedure.
\end{abstract}

Ukrainian educators and psychologists use techniques developed by both domestic and foreign authors. Domestic and post-Soviet methods are more widespread in the territory of Ukraine, while not all foreign ones have become widespread, which partially limits the diagnostic tools of practitioners.

The article deals with the twelve most popular methods of measuring the self-concept of children: Rosenberg Self Esteem Scale, Self Esteem Inventory, Piers-Harris Children's Self Concept Scale, Tennessee Self Concept Scale, Self Perception Profile for Children, Self Description Questionnaire, Self Perception Profile for Adolescents, Pictorial Scale of Perceived Competence and Acceptance for Young Children, Hare Self Esteem Scale, State Self Esteem Scale, Multidimensional Self Concept Scale, Martinek-Zaichkowsky Self Concept Scale for Children. The analysis shows that all methods have good indicators of validity, reliability and internal consistency. Some of them have been translated and adapted into Russian or Ukrainian. However, in most cases information about the psychometric properties of adapted versions of the methods is not disclosed by the authors. Only several versions of the Harter Self Perception Profile are presented in a format that allows their practical application. In addition, a number of methods (the Rosenberg test and the different versions of the Harter 
method) have good prospects for implementation in the educational process with proper standardization and additional studies of validity and reliability.

Keywords: self-concept, younger school age, psychodiagnostics, psychometrics.

\section{ВСТУП}

Постановка проблеми. Одним із найважливіших завдань освітнього процесу $є$ виховання цілісної особистості, розкриття особистісного потенціалу та врахування індивідуальних можливостей кожної дитини. Важливою передумовою реалізації цього завдання є виховання позитивної Я-концепції дітей, що становить основу їхнього самовизначення, ставлення до себе, взаємодії з ровесниками та дорослими. Я-концепція є достатньо складним, багаторівневим особистісним утворенням та визначає життєвий шлях людини. Процес виховання Я-концепції вимагає індивідуального підходу до дітей, саме тому якісна та своєчасна діагностика Я-концепції у школярів, підбір відповідних методик $є$ важливими для подальшого виховання позитивних уявлень про себе та самосприйняття.

Аналіз останніх досліджень і публікацій. Феномен Я-концепції розкритий такими зарубіжними вченими, як Р. Бернс, В. Джеймс, Е. Еріксон, Ч. Кулі, Дж. Мід, К. Роджерс, З. Фройд, та вітчизняними: К. Абульханова -Славська, Б. Ананьєв, М. Боришевський, Л. Божович, Р. Каламаж, І. Кон, О. Жигайло, С. Максименко, А. Налчаджян, О. Соколова, В. Столін, П. Чамата, І. Чеснокова та ін. Методи діагностики Я-концепції висвітлені у працях Л. Головей, О. Молчанової, Н. Радиної, Т. Рум'янцевої, С. Пантілєєва, Е. Терещенкової, А. Фурман, Н. Чернишевої.

МЕТА I ЗАВДАННЯ ДОСЛІДЖЕННЯ: систематизувати найпоширеніші стандартизовані зарубіжні методики дослідження Я-концепції школярів та проаналізувати їхні характеристики й психометричні властивості.

МЕТОДИ ДОсЛІДЖЕНня: у процесі роботи нами використано такі методи дослідження, як теоретикометодологічний аналіз наукових джерел, аналіз та систематизація наукової літератури з метою вивчення методик дослідження Я-концепції школярів та їх основних характеристик.

\section{РЕЗУЛЬТАТИ ДОСЛІДЖЕННЯ}

Освітній процес у Новій українській школі базується на принципах педагогіки партнерства. В основі цього підходу лежить співпраця між усіма учасниками цього процесу - учнями, вчителями, батьками. Вперше провідна роль у визначенні того, яким має бути навчання, надається самій дитині. Метою Нової української школи є виховання цілісної, усебічно розвинутої, самостійної, патріотично налаштованої особистості (Концепція Нової української школи, 2016). Очевидно, що досягнення цієї мети неможливе без надання належної уваги Я-концепції дитини.

Я-концепція особистості є динамічною системою уявлень людини про себе. До змісту Я-концепції належать уявлення про здібності та особистісні характеристики індивіда, про можливості взаємодії з іншими людьми та 3 навколишнім світом, ціннісні уявлення, що впливають на вибудовування поведінки людини. Досвід дитинства визначає подальше формування Я-концепції, вона зазнає змін протягом усього життя особистості, залежно від досвіду в різних сферах, але важливішими періодами, коли її становлення відбувається активно, є дитинство, виховання у сім'ї, період навчання у закладах освіти.

Діти приходять до першого класу 3 уже закладеними в дошкільному віці основами самосприйняття та самоставлення, на яких і має ґрунтуватись індивідуалізоване виховання їхньої Я концепції в школі. Відтак, неабияку значущість має вивчення особливостей Я-концепції дитини, а отже, і розроблення відповідних діагностичних методів та методик. Чільне місце серед таких методів посідають стандартизовані тести, які дозволяють швидко за усталеною процедурою вивчати особливості розвитку дітей та порівнювати отримані показники з нормативними даними.

Українські педагоги та психологи користуються методиками, розробленими як вітчизняними, так і зарубіжними авторами. На теренах України більш поширеними є вітчизняні методики та методики пострадянського простору, в той час, як не всі зарубіжні набули такого поширення, що частково обмежує діагностичний інструментарій вчителівпрактиків. На сьогоднішній день більш поширеними в зарубіжних публікаціях є 15 методик дослідження Я-концепції дітей та підлітків (Butler \& Gasson, 2005). Дванадцять з цих методик можуть застосовуватись для дослідження Я-концепції школярів. Узагальнені дані подано в таблиці 1.

Опитувальник самооцінки Розенберга (Rosenberg Self Esteem Inventory) є найбільш популярною методикою дослідження Я-концепції школярів. Остання англомовна версія опитувальника видана у 1989 poці (Rosenberg, 1989). Опитувальник містить 10 запитань, сформульованих позитивно («Я в цілому задоволений собою», «Я справляюсь із завданнями так само добре, як інші» тощо) чи негативно («Мені нічим гордитися», «я почуваюсь ні на що не здатним» тощо). Діти мають оцінити запропоновані твердження за чотирибальною шкалою: «погоджуюсь», «скоріше погоджуюсь». «скоріше не погоджуюсь», «не погоджуюсь». Психометричні властивості методики добре вивчені. Вона має високі показники внутрішньої узгодженості (до 0,88) та ретестової надійності (до 0,85). За задумом автора, методика має лише одну шкалу - самооцінки, однак окремі дослідження вказують на її двофакторну структуру (позитивна самооцінка та схильність до самознецінення). В літературі зустрічаються переклади методики російською та українською мовами, однак відомості щодо психометричних властивостей і навіть авторів перекладених методик не наводяться.

Опитувальник самооцінки Куперсміта (Self Esteem Inventory) є другим за популярністю на Заході та останній раз оновлювався у 2002 році (Соореrsmith, 2002). Методика містить 50 тверджень, на які дітям потрібно відповісти «Схоже на мене» чи «Не схоже на мене». Методика має добрі показники внутрішньої узгодженості (до 0,92) та ретестової надійності (до 0,88). За задумом автора, методика має одну узагальнювальну шкалу самооцінки та специфічні шкали, які вимірюють 4 сфери Я-концепції - загальну, соціальну, стосунки вдома, успішність в школі. 
Додатково опитувальник містить шкалу нещирості. Результати незалежних досліджень факторної структури опитувальника не збігаються з теоретичними формулюваннями автора. В різних дослідженнях у структурі цього опитувальника виділено 3, 5, 7 чи 9 факторів. У вітчизняній літературі опитувальник не згадується.

Таблиця 1

Найбільш поширені методики дослідження я-концепції школярів

\begin{tabular}{|c|c|c|c|c|c|}
\hline № & Оригінальна назва & $\begin{array}{c}\text { Назва адаптації/перекладу, } \\
\text { автор, рік (за наявності } \\
\text { відомостей) }\end{array}$ & $\begin{array}{l}\text { Вік } \\
\text { дітей }\end{array}$ & $\begin{array}{l}\text { Згадування } \\
\text { в Google } \\
\text { Scholar } \\
\text { (к-сть) }\end{array}$ & $\begin{array}{l}\text { Останнє } \\
\text { оновлення (рік, } \\
\text { автори) }\end{array}$ \\
\hline 1. & $\begin{array}{l}\text { Rosenberg Self Es- } \\
\text { teem Scale }\end{array}$ & Шкала самооцінки Розенберга & $11+$ & 38600 & 1989, Rosenberg \\
\hline 2. & Self Esteem Inventory & - & $8-15$ & 10300 & 2002, Coopersmith \\
\hline 3. & $\begin{array}{l}\text { Piers-Harris Chil- } \\
\text { dren's Self Concept } \\
\text { Scale }\end{array}$ & $\begin{array}{l}\text { Шкала Пирса - Харриса для } \\
\text { изучения Я-концепции, А. } \\
\text { Прихожан, } 2002\end{array}$ & $6-22$ & 9480 & $\begin{array}{l}\text { 2018, Piers Shem- } \\
\text { massian Herzberg } \\
\text { et al }\end{array}$ \\
\hline 4. & $\begin{array}{l}\text { Tennessee Self Con- } \\
\text { cept Scale }\end{array}$ & Шкала я-концепції Теннессі & $7+$ & 8750 & 1996, Fitts Warren \\
\hline 5. & $\begin{array}{l}\text { Self Perception Pro- } \\
\text { file for Children }\end{array}$ & $\begin{array}{l}\text { Методика изучения } \\
\text { дифференцированной } \\
\text { самооценки у детей младшего } \\
\text { школьного возраста, Н. } \\
\text { Чернышева, } 2005\end{array}$ & $8-15$ & 7850 & 2012, Harter \\
\hline 6. & $\begin{array}{l}\text { Self Description } \\
\text { Questionnaire }\end{array}$ & - & $7-13$ & 7000 & 1988, Marsh \\
\hline 7. & $\begin{array}{l}\text { Self Perception Pro- } \\
\text { file for Adolescents }\end{array}$ & $\begin{array}{l}\text { Самовосприятие подростков, Н. } \\
\text { Радина, Е. Терещенкова, } 2006\end{array}$ & $14-18$ & 3850 & 2012, Harter \\
\hline 8. & $\begin{array}{l}\text { Pictorial Scale of Per- } \\
\text { ceived Competence } \\
\text { and Acceptance for } \\
\text { Young Children }\end{array}$ & $\begin{array}{l}\text { Шкала самооценки } \\
\text { компетентности и социального } \\
\text { принятия дошкольника, Н. } \\
\text { Чернышева, } 2012\end{array}$ & До 7 & 3560 & 1984, Harter Pike \\
\hline 9. & $\begin{array}{l}\text { Hare Self Esteem } \\
\text { Scale }\end{array}$ & - & $10+$ & 1760 & 1975, Hare \\
\hline 10. & $\begin{array}{l}\text { State Self Esteem } \\
\text { Scale }\end{array}$ & - & - & 1750 & $\begin{array}{l}\text { 1991, Heatherton } \\
\text { Polivy }\end{array}$ \\
\hline 11. & $\begin{array}{l}\text { Multidimensional Self } \\
\text { Concept Scale }\end{array}$ & - & $9-19$ & 1020 & 1992, Bracken \\
\hline 12. & $\begin{array}{l}\text { Martinek-Zaich- } \\
\text { kowsky Self Concept } \\
\text { Scale for Children }\end{array}$ & - & $6-13$ & 105 & $\begin{array}{l}\text { 1977, Martinek } \\
\text { Zaichkowsky }\end{array}$ \\
\hline
\end{tabular}

Шкала дитячої Я-концепції Пірса-Гарріса (Piers-Harris Children's Self Concept Scale) € ще однією популярною методикою дослідження Я-концепції школярів. Остання редакція методики англійською мовою видана у 2018 році (Piers et. al., 2018). Це видання опитувальника містить 58 тестових запитань, на які учні можуть відповісти «Так» або «Ні». Запитання сформовані на основі опитування дітей щодо тем, які їх турбують. Частина тверджень сформульована позитивно («Я сильний», «Я гарно малюю», «В мене гарні очі» тощо), частина - негативно («З мене всі сміються», «Я незграбний», «Я роблю багато поганих речей»). Існує безліч досліджень психометричних властивостей методики, які показують її добру внутрішню узгодженість (до 0,91) та ретестову надійність (до 0,75). Факторна структура методики включає загальний рівень самооцінки та оцінку шести специфічних сфер Я-концепції: поведінку, свободу від тривоги, щастя та задоволення, інтелектуальні здібності й шкільну успішність, тілесні властивості та зовнішність, соціальну адаптацію. Додатково вимірюється схильність давати випадкові або соціально бажані відповіді.

Російською мовою першу редакцію методики переклала А. Прихожан (2005). Авторка доповнила методику шкалою для виявлення в учнів тенденції давати соціально бажані відповіді. Адаптація методики має 90 запитань, на які дітям пропонується дати відповіді за чотирибальною шкалою: «неправильно», «скоріше неправильно», «скоріше правильно», «правильно». При підрахунках результатів ці відповіді інтерпретуються за двобальною шкалою («+» або «-»). Авторка стверджує, що нею здійснені дослідження валідності та надійності методики, її факторної структури, емпірично встановлено відповідні вікові норми. В публікаціях методики посилань на відповідні дослідження немає. Запропонована авторкою факторна структура методики включає 9 вторинних шкал: поведінка, інтелект та успішність в школі, ситуація в школі, зовнішність та тілесні властивості, тривожність, спілкування, щастя та задоволення, становище в сім'ї, впевненість у собі. 
Шкала Я-концепції Теннессі (Tennessee Self Concept Scale) останній раз оновлювалась у 1996 році (Fitts \& Warren, 1996). Методика містить 82 твердження, які дітям потрібно оцінити за 5 бальною шкалою від «завжди не правильно» до «завжди правильно». Приклади таких тверджень: «я ніхто», «Я ставлюсь до своїх батьків достатньо добре», «Я приваблива людина», «Інколи я думаю про речі, надто погані, щоб про них розказувати» тощо. Існує дві версії опитувальника - для дітей та для дорослих. Методика має добрі показники внутрішньої узгодженості (до 0,92) та ретестової надійності (до 0,90). Методика має 4 шкали для контролю валідності результатів (неузгодженість результатів, самокритичність, бажання здаватись хорошим, схильність до крайнощів), 2 загальні шкали (самооцінки та внутрішнього конфлікту), 6 шкал за різними сферами я-концепції (фізична, моральна, особиста, сімейна, соціальна, навчальна), 3 додаткові шкали (ідентичність, задоволення, поведінка). Тобто, методика має доволі складну структуру. Однак емпіричні дослідження із застосуванням факторного аналізу не підтверджують факторну структуру, запропоновану авторами методики. Методика згадується в україномовній та російськомовній літературі, однак публікацій її перекладу нами не знайдено.

Профіль самосприйняття для дітей Хартер (Self Perception Profile for Children) останній раз оновлювався у 2012 році (Harter, 2012b). Методика складається з 36 пар тверджень, які дітям пропонується оцінити за розробленою авторкою спеціально для цього опитувальника шкалою структурованих альтернатив.

Кожне завдання тесту складається з двох альтернатив, наприклад: «Деякі діти часто забувають те, що вони вчать» та «Інші діти легко все запам'ятовують». Спершу дитина має обрати, на яку категорію дітей вона схожа. Потім дитина має оцінити, наскільки вона схожа на дітей цієї категорії, обравши з двох варіантів: «Дещо схоже на мене» та «Дуже схоже на мене». За задумом авторки, такий підхід має зменшити вплив на дітей схильності давати соціально бажані відповіді.

Методика Хартер має добрі показники внутрішньої узгодженості (до 0,91). Результатів досліджень ретестової надійності авторка не повідомляє, що зумовлено нестійкістю Я-концепції як явища. Результати факторного аналізу методики в цілому збігаються із запропонованою авторкою шкальною структурою. Методика містить узагальнювальну шкалу самооцінки та 5 субшкал: навчальної, соціальної, спортивної, фізичної та поведінкової компетентності.

У 2005 році Н. Чернишева представила російський переклад методики Хартер, яку авторка назвала «Методика изучения дифференцированной самооценки у детей младшего школьного возраста» (Чернышева, 2005). Переклад містить 28 пар тестових тверджень, які дітям необхідно оцінити за шкалою структурованих альтернатив Хартер. Підрахунок результатів здійснюється за 4 шкалами - пізнавальної компетентності, компетентності у спілкуванні $з$ однолітками, компетентності у позакласній діяльності, загального самоприйняття.

Опитувальник самоопису Марша (Self Description Questionnaire). Опитувальник містить 136 тверджень, які дітям пропонується оцінити за восьмибальною шкалою від «Зовсім неправильно» до «Цілком правильно». Методика має добру внутрішню узгодженість (в середньому - 0,89). Показники ретестової надійності невідомі. Факторна структура опитувальника включає один загальний показник самооцінки та 12 специфічних: математичні здібності, вербальні здібності, успішність в навчанні, креативність, успіхи в спорті, зовнішність, стосунки з однолітками, стосунки з однолітками протилежної статі, стосунки з батьками, духовність, чесність, емоційна стабільність.

Профіль самосприйняття для підлітків Хартер (Self Perception Profile for Adolescents) оновлений у 2012 році (Наarter, 2012a). Методика є розширеною версією Профіля самосприйняття для дітей Хартер, а отже? має подібну структуру запитань та добрі психометричні властивості. Всього методика містить 45 пар тверджень, має одну загальну шкалу самооцінки та 8 специфічних шкал - навчальної, соціальної, спортивної, професійної компетентності, зовнішнього вигляду, привабливості, поведінки, дружби.

Російською мовою методику переклали та адаптували Н. Радіна та О. Терещенкова (2006). Структура методики в цілому відповідає оригіналу. Даних щодо психометричних властивостей методики нами не знайдено.

Рисунковий тест самооцінки компететності та соціального прийняття для дошкільників (Pictorial Scale of Perceived Competence and Acceptance for Young Children) опублікований в 1984 році (Harter \& Pike, 1984). Методика $€$ адаптацією Профілю самосприйняття для дітей Хартер для дітей, які не вміють читати. Тест складається з 24 пар картинок. На одній картинці з пари зображено компетентну дитину, на другій - некомпетентну. Дітям зачитується опис картинок та пропонується обрати, який з персонажів більш схожий на них. Наприклад, на одній парі картинок зображено дівчинку, що складає пазли. На першій картинці з пари пазл складений, на другій - розкиданий. Підписи до картинок: «Дитина добре складає пазли» та «Дитина не дуже добре складає пазли» відповідно. Обрану картинку з пари дитина може оцінити за двобальною шкалою: «Дещо схоже на мене» та «Дуже схоже на мене».

Методика має достатні показники внутрішньої узгодженості (до 0,84). Дані про ретестову надійність не наводяться. До факторної структури методики входить 4 шкали: когнітивна компетентність, фізична компетентність, прийняття однолітками та прийняття матір'ю.

Російськомовна адаптація методики опублікована в 2012 році Н. Чернишевою (Чернишева, 2012). Адаптація відповідає оригіналу. Авторка повідомляє про добру внутрішню узгодженість методики $(0,85)$ та наводить відомості щодо її конвергентної валідності.

Шкала самооцінки Хейра (Hare Self Esteem Scale) опублікована в 1975 році (Hare, 1975). Методика містить 30 тверджень, які діти мають оцінити за чотирибальною шкалою: «Не погоджуюсь», «Скоріше не погоджуюсь», «Скоріше погоджуюсь» та «Погоджуюсь». Методика має прийнятну ретестову надійність (до 0,74). Оцінка внутрішньої узгодженості авторами не проводилась. Факторна структура методики охоплює три компоненти: самооцінку в школі, вдома та в стосунках з друзями. Методика згадується в поодиноких україномовних та російськомовних працях. 
Шкала ситуативної самооцінки Хітертона та Полівого (State Self Esteem Scale) опублікована у 1991 році та спрямована на дослідження особливостей ставлення дітей до самих себе «тут і тепер» (Heatherton \& Polivy, 1991). Методика містить 20 тверджень, які діти мають оцінити за п'ятибальною шкалою від «Точно ні» до «Точно так». Методика має добру внутрішню узгодженість (до 0,92) та достатню ретестову надійність (до 0,72). Варто зазначити, що за задумом авторів методика має вимірювати нестійку в часі характеристику, відтак вимог до ретестової надійності автори не ставлять. Емпірично підтверджена факторна структура методики містить один загальний показник самооцінки та три специфічні - самооцінку продуктивності, соціальну самооцінку та самооцінку зовнішності. У вітчизняній літературі методика не згадується.

Багатовимірна шкала Я-концепції Бракена (Multidimensional Self Concept Scale) опублікована у 1992 році. Методика містить 150 тверджень, які учням пропонується оцінити за чотирибальною шкалою від «зовсім не погоджуюсь» до «цілком погоджуюсь». Дослідження психометричних властивостей методики показують її добру внутрішню узгодженість (до 0,99) та ретестову надійність (до 0,90). Методика оцінює Я-концепцію особистості за загальним показником та 6 специфічними показниками: соціальним, компетентнісним, афективним, навчальним, сімейним та фізичним. Результати факторного аналізу методики збігаються з теоретичними формулюваннями автора. У вітчизняній літературі методика не згадується.

Шкала Я-концепції для дітей Мартінека-Заїчковського (Martinek-Zaichkowsky Self Concept Scale for Children) опублікована в 1977 році. Тест є невербальним та культурно незалежним. Методика може застосовуватись до дітей, які не вміють читати. Дітям пропонуються пари картинок, з яких вони мають обрати ту, яка найбільше схожа на них. Наприклад, на першій картинці з дванадцятої пари зображено жінку, яка дає зубну щітку та пасту похмурій дівчинці, яка пручається. На другій картинці з цієї пари зображено дівчинку, яка самостійно чистить зуби. Методика має добру внутрішню узгодженість (до 0,92). Інформація про ретестову надійність методики відсутня. Методика проектувалась як однофакторний інструмент для визначення загального рівня самооцінки, однак в дослідженнях показана п'ятифакторна структура методики з такими компонентами: задоволення, ситуація в сім'ї, здібності в спорті, особистість, поведінка в школі. У вітчизняній літературі методика не згадується.

\section{ВИСНОВКИ ТА ПЕРСПЕКТИВИ ПОДАЛЬШИХ ДОСЛІДЖЕНЬ}

У вітчизняній літературі зарубіжні методики дослідження Я-концепції школярів висвітлені в недостатньому обсязі, у більшості випадків відомості щодо психометричних властивостей адаптованих версій методик не розкриваються. При цьому адаптувались переважно застарілі версії методик. Лише окремі версії методики самосприйняття Хартер представлені у форматі, який дозволяє їх повноцінне практичне застосування.

Водночас варто відзначити ті методики, які за належного доопрацювання мають добрі перспективи впровадження в практику навчально-виховної діяльності. В першу чергу йдеться про методику Розенберга, яка вже перекладена українською, однак потребує стандартизації, нормалізації та валідизації. Методика $€$ загальновизнаним світовим стандартом, вимагає мінімум зусиль для проведення та розповсюджується під вільною ліцензією. Також під вільною ліцензією розповсюджується методика Хартер, яку варто оновити, а також стандартизувати й здійснити дослідження ї̈ валідності та надійності. Впровадження цієї методики в практику діяльності дозволить вивчати Я-концепцію дітей більш поглиблено та якісно.

Таким чином, дослідження Я-концепції молодших школярів може ефективно здійснюватися за умови використання надійних апробованих методик. Дослідження не вичерпало усіх можливостей і потребує проведення констатувальних зрізів, їх аналізу та глибокого вивчення з метою розробки й впровадження особистісно орієнтованої технології виховання Я-концепції.

\section{СПИСОК ВИКОРИСТАНИХ ДЖЕРЕЛ}

Концепція Нової української школи (2016). URL: https://www.kmu.gov.ua/ storage/app/media/reforms/ukrainska-shkola-compressed.pdf Прихожан, А. М., Толстых, Н. Н. (2005). Психология сиротства. Санкт-Петербург : Питер.

Радина, Н. К., Терещенкова, Е. Ю. (2006). Личностный опросник С. Хартер - психодиагностический инструмент нового поколения для изучения персональной идентичности подростка. Психология и школа, 4, 3-20.

Чернышева, Н. (2005). Характер младшего школьника. Москва : Наука, Флинта.

Чернышева, Н. С. (2012). Шкала самооценки компетентности и социального принятия дошкольника (С. Хартер и Р. Пайк). Вестн. КРАУНЦ Гуманитарные науки, 2 (20), 155 - 164.

Bracken, B. A. (1992). Multidimensional Self Concept Scale. Austin, TX: Pro-Ed.

Butler, R. J., \& Gasson, S. L. (2005). Self esteem/self concept scales for children and adolescents: A review. Child and Adolescent mental health, $10(4), 190-201$.

Coopersmith, S. (2002). Revised Coopersmith self-esteem inventory manual. Redwood City: Mind Garden.

Gilberts, R. (1983). The evaluation of self-esteem. Family \& Community Health, 6 (2), 29-49.

Hare, B.R. (1975). The HARE general and area-specific (school, peer, and home) self esteem scale. Unpublished manuscript, Department of Sociology, SUNY Stony Brook, Stony Brook, New York.

Harter, S. (2012a). Self-perception profile for adolescents: Manual and questionnaires. Denver, CO: Univeristy of Denver, Department of Psychology.

Harter, S. (2012b). Self-perception profile for children: manual and questionnaires (grades 3-8). Denver, CO: University of Denver.

Harter, S., Pike, R. (1984). The Pictorial Scale of Perceived Competence and Social Acceptance for Young Children. Child Development, 55 (6), 1969-1982.

Heatherton, T. F., \& Polivy, J. (1991). Development and validation of a scale for measuring state self-esteem. Journal of Personality and Social psychology, 60 (6), 895. 
Hoffman, R. G., Davis, G. L., \& Nelson, K. S. (1988). Factor analysis of the Tennessee Self-Concept Scale in an adolescent sample. Educational and psychological measurement, 48 (2), 407-417.

Piers, E.V. Shemmassian, S.K Herzberg, D.S, \& Harris, D.B (2018). Piers-Harris Self-Concept Scale - Third Edition (Piers-Harris 3). Los Angeles, CA. Western Psychological Services.

Rosenberg, M. (1989). Society and the adolescent self- image. Revised edition. Middletown, CT: Wesleyan University Press.

Fitts, W. H., \& Warren, W. L. (1996). Tennessee self-concept scale: TSCS-2 (p. 118). Los Angeles: Western Psychological Services.

\section{REFERENCES}

Kontesptsiia Novoi ukrainskoi shkoly. (2016). Retreived from: https://www.kmu.gov.ua/storage/app/media/reforms/ukrainska-shkola-compressed.pdf Prijhozhan, A. M., Tolstykh, N. N. (2005). Psikholohiia sirotstva. St. Petersburg: Piter.

Radina, N. K., Tereshchenkova, E. Yu. (2006). Lichnostnyi oprosnik S. Kharter - psikhodiagnosticheskii instrument novoho pokoleniia dlia izucheniia personalnoi identichnosti podrostka. Psikholohiia i shkola, 4, 3-20.

Chernysheva, N. S. (2005). Kharakter mladsheho shkolnika. M. : Nauka, Flinta.

Chernysheva, N. S. (2012). Shkala samootsenki kompetentnosti i sotsialnoho priniatiia doshkolnika (S. Kharter, R. Paik). Vestn. KRAUNTs Gumanitarnye nauki, 2 (20), 155-164.

Bracken, B. A. (1992). Multidimensional Self Concept Scale. Austin, TX: Pro-Ed.

Butler, R. J., \& Gasson, S. L. (2005). Self esteem/self concept scales for children and adolescents: A review. Child and Adolescent mental health, 10 (4), $190-201$.

Coopersmith, S. (2002). Revised Coopersmith self-esteem inventory manual. Redwood City: Mind Garden.

Gilberts, R. (1983). The evaluation of self-esteem. Family \& Community Health, 6 (2), 29-49.

Hare, B.R. (1975). The HARE general and area-specific (school, peer, and home) self esteem scale. Unpublished manuscript, Department of Sociology, SUNY Stony Brook, Stony Brook, New York.

Harter, S. (2012a). Self-perception profile for adolescents: Manual and questionnaires. Denver, CO: Univeristy of Denver, Department of Psychology.

Harter, S. (2012b). Self-perception profile for children: manual and questionnaires (grades 3-8). Denver, CO: University of Denver.

Harter, S., Pike, R. (1984). The Pictorial Scale of Perceived Competence and Social Acceptance for Young Children. Child Development, 55 (6), 1969-1982.

Heatherton, T. F., \& Polivy, J. (1991). Development and validation of a scale for measuring state self-esteem. Journal of Personality and Social psychology, 60 (6), 895.

Hoffman, R. G., Davis, G. L., \& Nelson, K. S. (1988). Factor analysis of the Tennessee Self-Concept Scale in an adolescent sample. Educational and psychological measurement, $48(2), 407-417$.

Piers, E.V. Shemmassian, S.K Herzberg, D.S, \& Harris, D.B (2018). Piers-Harris Self-Concept Scale - Third Edition (Piers-Harris 3). Los Angeles, CA. Western Psychological Services.

Rosenberg, M. (1989). Society and the adolescent self- image. Revised edition. Middletown, CT: Wesleyan University Press.

Fitts, W. H., \& Warren, W. L. (1996). Tennessee self-concept scale: TSCS-2 (p. 118). Los Angeles: Western Psychological Services. 